\title{
Peningkatan Keterampilan tentang Cara Mencuci Tangan yang Benar pada Siswa SDN 03 Cintakarya Pangandaran
}

\author{
Umar Sumarna ${ }^{1}$, Dadang Purnama ${ }^{2}$, Udin Rosidin ${ }^{3}$ \\ ${ }^{1}$ Universitas Padjadjaran, Jalan Raya Bandung-Sumedang Km 21 Jatinangor 45363 \\ Email: umar.sumarna@unpad.ac.id ${ }^{1}$
}

\begin{abstract}
ABSTRAK
Berbagai macam penyakit infeksi menular tumbuh dengan subur di Indonesia sampai ke pelosok-pelosok, yaitu ke tiap provinsi, lalu ke tiap kota dan kabupaten, termasuk Kabupaten Pangandaran. Hal ini jelas akan menurunkan derajat kesehatan masyarakat di Kabupaten Pangandaran. Panyebab dari semua kejadian ini yang paling utama adalah dilatarbelakangi oleh perilaku masyarakat yang salah dalam hal kebiasaan mencuci tangan, sehingga penularan penyakit infeksi mudah terjadi dan menyebar dimana-mana. Tujuan dari penyuluhan ini adalah menurunkan angka kejadian penyakit infeksi, tim pengabdian mengadakan penyuluhan tentang cara mencuci tangan yang benar pada siswa Sekolah Dasar Negeri 03 Cintakarya Kabupaten Pangandaran. Metode yang digunakan adalah demonstrasi yang diperagakan pada 67 siswa di lingkungan sekolah bersama mahasiswa Fakultas Keperawatan Universitas Padjadjaran Kampus Pangandaran. Hasil yang didapatkan dari penyuluhan ini adalah terjadinya peningkatan keterampilan dimana pada awalnya jumlah siswa dengan kategori keterampilan tinggi sebesar 10,45\%, keterampilan sedang sebesar 58,21\%, dan keterampilan rendah sebesar 31,34\% menjadi kategori keterampilan tinggi sebesar $73,13 \%$, keterampilan sedang sebesar $26,87 \%$, dan keterampilan rendah tidak ada. Kemudian demonstrasi diulang pada siswa yang berketerampilan sedang, sehingga akhirnya semua siswa mendapat kategori keterampilan tinggi. Kesimpulan dari penyuluhan ini menyatakan bahwa semua siswa Sekolah Dasar Negeri 03 Cintakarya Pangandaran dapat menangkap materi penyuluhan sekaligus mempraktekkannya dengan baik, walaupun daya tangkap mereka dalam menyerap dan menerapkan materi penyuluhan berbeda-beda.
\end{abstract}

Kata kunci: Penyakit infeksi, Cuci tangan, Peningkatan keterampilan.

\begin{abstract}
Various infectious diseases thrive in Indonesia to the corners, namely to each province, then to each city and district, including Pangandaran Regency. This will lower the degree of public health in the Pangandaran Regency. The main cause of all these events is motivated by the community's wrong behavior in terms of handwashing habits. The transmission of infectious diseases quickly occurs and spreads everywhere. This counseling aims to reduce the incidence of infectious diseases. The service team held counseling on washing hands properly in the students of Public Elementary School 03 Cintakarya Pangandaran Regency. The method used was a demonstration that was demonstrated on 67 students in the school environment with students of the Faculty of Nursing Universitas Padjadjaran Pangandaran Campus. The result of this counseling is the improvement of skills where initially the number of students with high skill category by $10.45 \%$, medium skills by $58.21 \%$, and low skills by $31.34 \%$ into high skill category by $73.13 \%$, medium skills by $26.87 \%$, and low skills does not exist. The demonstration was then repeated on moderately skilled students so that eventually, all students got a high skill category. This counseling states that all students of Public Elementary School 03 Cintakarya Pangandaran can capture the counseling material and practice it well. However, their capture in absorbing and applying counseling materials varies.
\end{abstract}

Keyword: Infection Diseases, Washing hand, Skill increase 


\section{PENDAHULUAN}

Berbagai macam penyakit yang disebabkan oleh mikroorganisme atau kuman, biasa juga disebut penyakit infeksi atau penyakit menular, disebut demikian karena jenis penyakit ini dapat ditularkan secara langsung maupun tidak langsung (Kemenkes RI, 2014). Penularan secara langsung terjadi ketika kuman pada orang yang sakit berpindah melalui kontak fisik, misalnya lewat sentuhan dan ciuman, melalui udara saat bersin dan batuk, atau melalui kontak dengan cairan tubuh seperti urine dan darah. Orang yang menularkannya bisa saja tidak memperlihatkan gejala dan tidak tampak seperti orang sakit, apabila dia hanya sebagai pembawa penyakit, yang kita sebut sebagai carrier (Najmah,2016).

Penyakit menular juga dapat berpindah secara tidak langsung, dimana penyebarannya terjadi melalui media perantara seperti saat menyentuh knop pintu, keran air, atau tiang besi pegangan di kereta yang terkontaminasi (Widoyono, 2012). Kemudian menginfeksi tubuh kita pada saat tangan kita menyentuh mata, hidung, atau mulut tanpa mencuci tangan terlebih dahulu setelah menyentuh benda-benda yang telah terkontamisi tersebut.

Penyakit menular umumnya lebih berisiko mengenai orang yang memiliki daya tahan tubuh lemah dan tinggal di lingkungan dengan kondisi kebersihan yang kurang baik (Maryunani, 2013). Berbagai macam mikroorganisme yang menimbulkan penyakit menular adalah virus, bakteri, parasit, atau jamur (Murwani, 2015). Penyakit-penyakit yang ditimbulkannya antara lain tuberkulosis, hepatitis, campak, cacar air, chikungunya, malaria, HIV/AIDS, pneumonia, rabies, influenza, rabies, flu burung, COVID 19, cacingan dan lain-lain.

Beberapa diantara penyakit tersebut dapat dihindari dengan perilaku cuci tangan pakai sabun (Murwanto, 2017), terutama penyakit cacingan yang sering diderita oleh anak-anak. Perilaku cuci tangan yang benar seharusnya sudah diajarkan sejak masih anak-anak. Banyaknya kasus cacingan disebabkan oleh kesukaan anak-anak bermain-main dengan tanah dan memegang benda-benda kotor, kemudian memegang makanan dan memasukkannya ke dalam mulut tanpa mencuci tangan terlebih dahulu, atau cara mencuci tangannya yang tidak benar.

Menurut WHO (2013), parasit menginfeksi lebih dari 2 miliar orang di dunia dan 880 juta diantaranya terjadi pada anak usia sekolah (6-14 tahun). Berdasarkan data tersebut prevalensi terbesar terjadi pada anak usia sekolah. WHO (2013) juga melaporkan bahwa terdapat 6 wilayah endemik di dunia yang menjadi prioritas untuk pengobatan infeksi 
cacing pada anak, yaitu Asia Tenggara yang menempati prioritas pertama sebesar $42 \%$ di atas Afrika sebesar 32\%, Pasific Barat sebesar 11\%, Mediterania Timur sebesar 9\%, Amerika sebesar 5\%, dan Eropa sebesar 1\%.

Sebagai negara yang termasuk dari kawasan Asia Tenggara, Indonesia memiliki banyak kasus cacingan pada anak-anak balitanya. Sehingga mendapat prioritas kebutuhan pengobatan cacingan yang dianggarkan oleh WHO. Di Asia Indonesia menempati urutan kedua dengan mendapat jatah $15 \%$ di bawah India dengan jatah 61\%, sementara negara-negara Asia berikutnya, Bangladesh 13\%, Myanmar 3\%, Nepal 3\%, Korea Utara $1 \%$, dan negara lainnya $1 \%$.

Provinsi Jawa Barat sebagai salah satu wilayah yang menjadi bagian dari wilayah Indonesia juga memiliki gambaran tentang tingginya kasus cacingan pada anak, yaitu berada di kisaran 60\%-70\%. Dari segi jumlah kasus Dinkes Prop.Jabar (2015), melaporkan bahwa siswa SD dan SMP di Jabar mencapai 7.427 .862 orang dan 60\% dari jumlah tersebut mengidap penyakit cacingan.

Kabupaten Pangandaran adalah sebuah kabupaten di Provinsi Jawa Barat, memiliki jumlah Sekolah Dasar (SD) sebanyak 295 buah, salah satunya adalah SDN 03 Cintakarya yang terletak di Jalan Karang kamulyan no. 57, Desa Cintakarya, Kecamatan. Parigi. Jumlah guru di sekolah tersebut berjumlah 10 orang, siswanya berjumlah 106 orang, terdiri dari laki-laki 59 orang dan perempuan 47 orang.

Pada saat tim pengabdian mengunjungi SDN 03 Cintakarya dan mewawancarai 20 orang siswa kelas 5 dan 6 tentang kebiasaan mencuci tangan sebelum makan. Pada dasarnya siswa-siswi tersebut sudah membiasakan diri untuk mencuci tangan. Tapi tak seorangpun di antara mereka yang mengetahui tentang langkah-langkah atau cara mencuci tangan yang benar menurut kesehatan, bahkan sering tidak memakai sabun. Menurut Evayanti (2014) cuci tangan dengan sabun merupakan salah satu usaha untuk mencegah penyakit, karena tangan merupakan anggota tubuh yang paling sering bersentuhan dengan barang yang belum tentu bersih dan bisa saja barang tersebut mengandung ribuan mikroorganisme penyebab penyakit. Sementara Rosyidah (2014), mengatakan bahwa 98 persen penyebaran kuman di tubuh bersumber dari tangan.

Mungkin saja Kabupaten Pangandaran merupakan salah satu penyumbang data atas tingginya kasus cacingan di Jawa Barat, khususnya siswa SDN 03 Cintakarya dengan melihat kenyataan tentang pengetahuan siswa di atas tentang cara mencuci tangan dengan benar. 
Dalam program pengabdian ini, tim pengabdian bertujuan untuk mengetahui apakah akan terjadi peningkatan keterampilan pada siswa SDN 03 Cintakarya Pangandaran tentang cara-cara dan langkah-langkah mencuci tangan yang benar menurut kesehatan antara sebelum dan sesudah diberi penyuluhan.

\section{METODE}

Perilaku mencuci tangan sebelum makan sudah biasa dilakukan oleh sebagian besar oleh siswa SDN 03 Cintakarya. Namun yang menjadi masalah kesehatan pada siswa adalah ketidaktahuan mereka mengenai cara mencuci tangan yang benar menurut kesehatan. Untuk menanggulangi keadaan ini, tim pengabdian mengadakan penyuluhan dengan teknik demonstrasi.

Pelaksanaan pengabdian ini dilaksanakan pada tanggal 15 s.d 18 Desember 2019 oleh tim pengabdian selaku tim dosen Universitas Padjadjaran sebanyak 3 orang dengan melibatkan mahasiswa Fakultas Keperawatan Universitas Padjadjaran PSDKU Pangandaran sebanyak 8 orang. Demikian juga kepala sekolah SDN 03 Cintakarya dengan beberapa stafnya dilibatkan dalam mempersiapkan beberapa siswanya yang akan dijadikan sasaran penyuluhan.

Pengabdian dilakukan melalui langkah-langkah:

1. Persiapan seperti melakukan survey, penetapan kelompok sasaran, mengidentifikasi masalah, pembuatan proposal, dan persiapan alat-alat.

2. Menyusun materi dengan pokok bahasan "Langkah-langkah Mencuci tangan yang Benar", sebagai berikut:

a. Gosokan telapak tangan kiri dengan telapak tangan kanan.

b. Telapak tangan kanan diatas punggung tangan kiri dan lakukan sebaliknya

c. Telapak tangan kanan dan kiri, jari kanan dan kiri saling terkait.

d. Letakkan punggung jari pada telapak satunya dengan jari saling mengunci.

e. Jempol kanan digosok memutar oleh telapak kiri, dan lakukan sebaliknya.

f. Jari kiri menguncup, gosok memutar ke kanan dan ke kiri pada telapak tangan kanan, kemudian sebaliknya.

g. Pegang pergelangan tangan kiri dengan tangan kanan dan sebaliknya, gerakan memutar. 


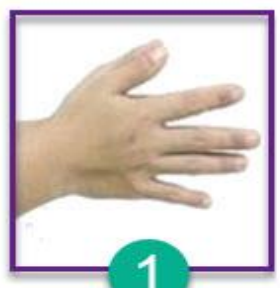

1

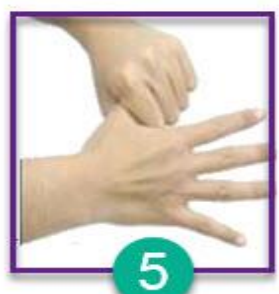

5
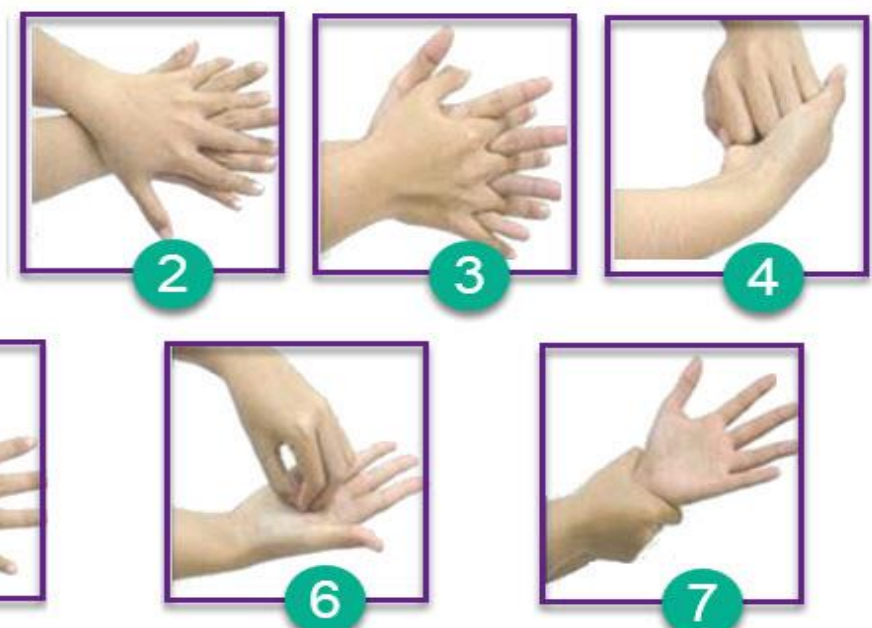

6

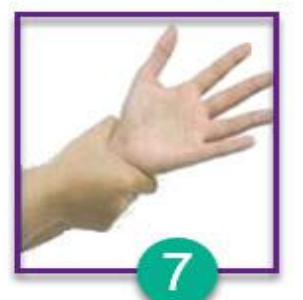

7

Gambar 1: Langkah-langkah Mencuci Tangan yang Benar

3. Melakukan penyuluhan pada siswa kelas 5 dan 6 SDN 03 Cintakarya dengan menjelaskan langkah-langkah mencuci tangan yang benar dan pakai sabun menurut Pusdatin Kemenkes RI (2014). Dijelaskan pula tentang penggunaan hand sanitizer yang dapat digunakan langsung tanpa harus dibilas terlebih dahulu. Berarti penggunaan hand sanitizer lebih efektif daripada penggunaan sabun (Desiyanto \& Djannah 2013).

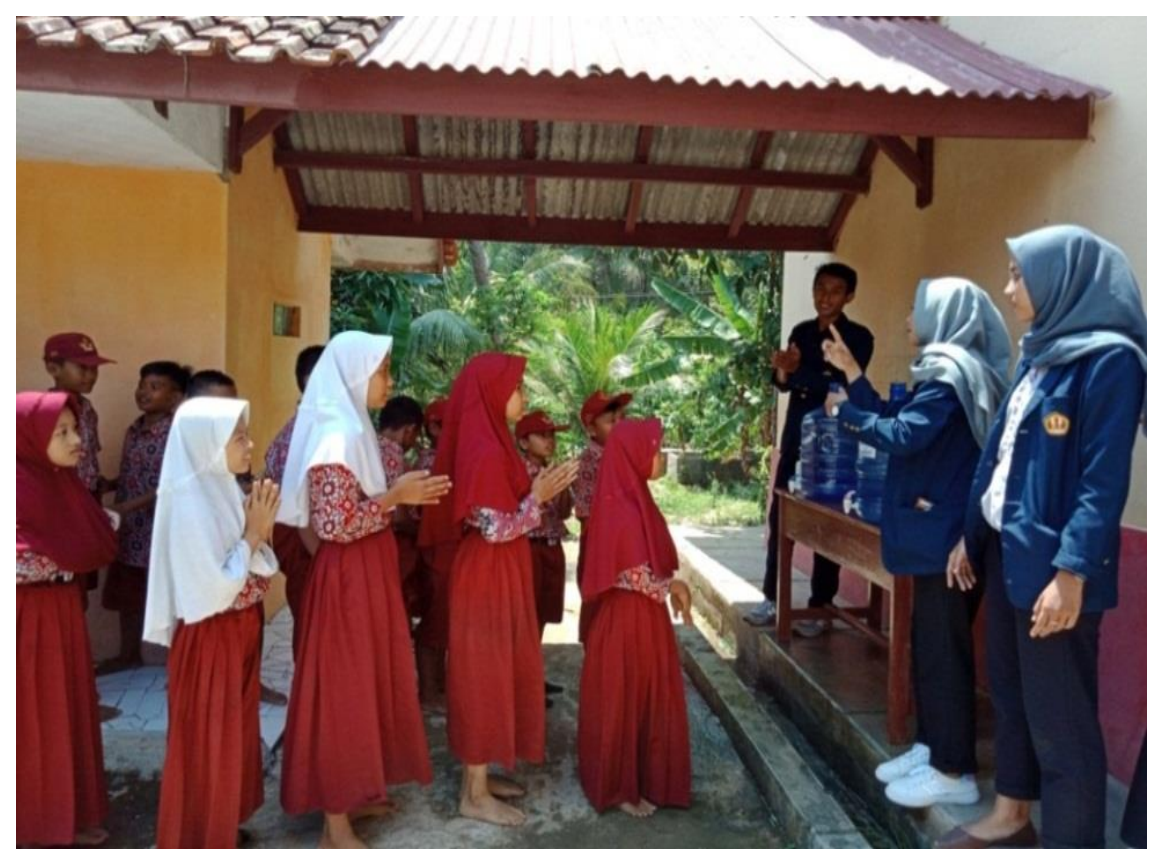

Gambar 2: Pelaksanaan Penyuluhan dengan Teknik Demonstrasi

4. Melakukan evaluasi, yang terdiri dari pretes, berupa tes cuci tangan sebelum penyuluhan dilaksanakan dan postes yang dilaksanakan sesudah penyuluhan. Alat penilaian hasil tes menggunakan kuisioner Standar Operasional Prosedur (SOP). 
Hasilnya dikelompokkan dalam tiga kategori, yaitu: Tinggi (76-100), Sedang (56-75), dan Rendah (0-55). Kemudian hasil pretes dan postes dibandingkan.

\section{HASIL, PEMBAHASAN, DAN DAMPAK}

Hasil dari penyuluhan dapat dilihat dengan membandingkan pretes dan postes dari siswa SDN 03 Cintakarya seperti dalam grafik gambar 3.

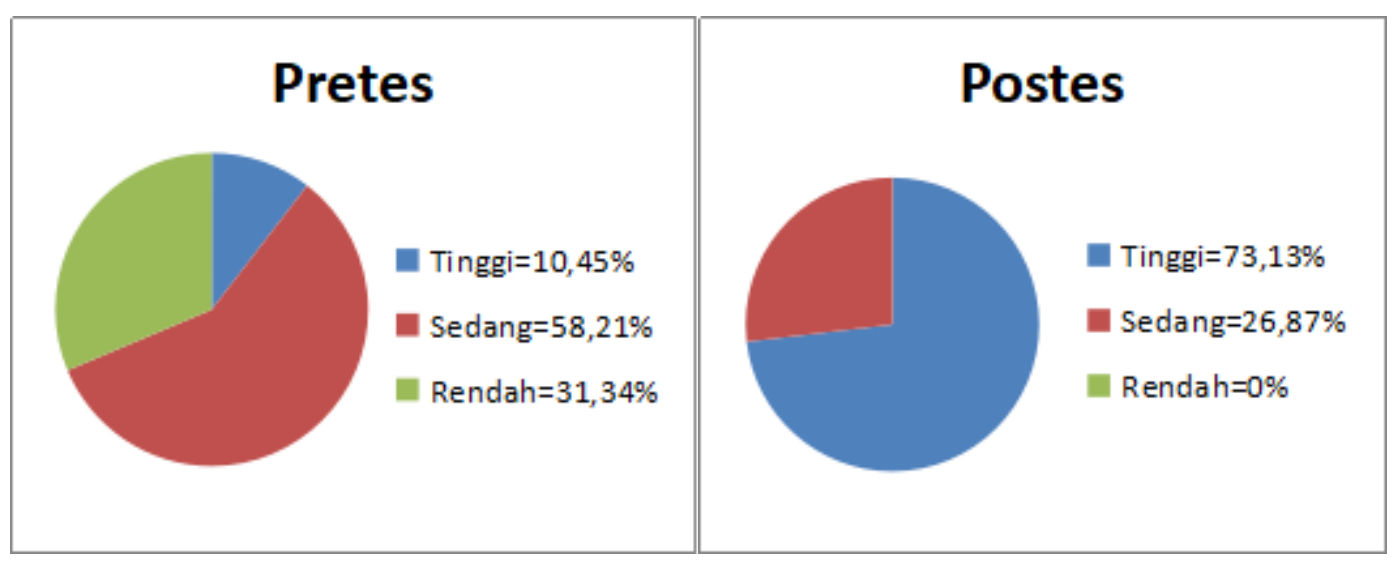

Gambar 3: Hasil Pretes dan Postes

Berdasarkan grafik di atas, ternyata terjadi peningkatan besar-besaran tentang tingkat keterampilan siswa SDN 03 Cintakarya, dimana siswa dengan tingkat ketrampilan tinggi dari $10,45 \%$ meningkat secara pesat menjadi $73,13 \%$. Sementara siswa dengan tingkat keterampilan rendah dari $31,34 \%$ menjadi nihil. Hal ini membuktikan bahwa untuk mempelajari langkah-langkah mencuci tangan yang benar sangat mudah untuk dipelajari.

Sesungguhnya kami sangat mengharapkan bahwa siswa yang berada di tingkat keterampilan sedang sebesar 26,87\% semuanya berada di tingkat keterampilan tinggi. Sehingga tim pengabdian melakukan demonstrasi ulang dan dengan tidak memakan waktu lama merekapun dapat mempraktekkan cara mencuci tangan dengan benar secara sempurna, maka hasil akhir menjadi seluruh siswa mendapat kategori memiliki keterampilan tinggi.

Pada kesempatan ini kami menyampaikan pesan dan harapan kepada siswa yang sudah dilatih supaya selalu menerapkan langkah-langkah mencuci tangan tersebut dalam kehidupan sehari-hari terutama sebelum dan sesudah makan atau sesudah memegang benda-benda kotor atau terkontaminasi, kemudian ditularkan kepada teman-teman atau adik-adik kelasnya, bahkan alangkah baiknya bila ditularkan kepada seluruh keluarganya yang ada di rumah. 


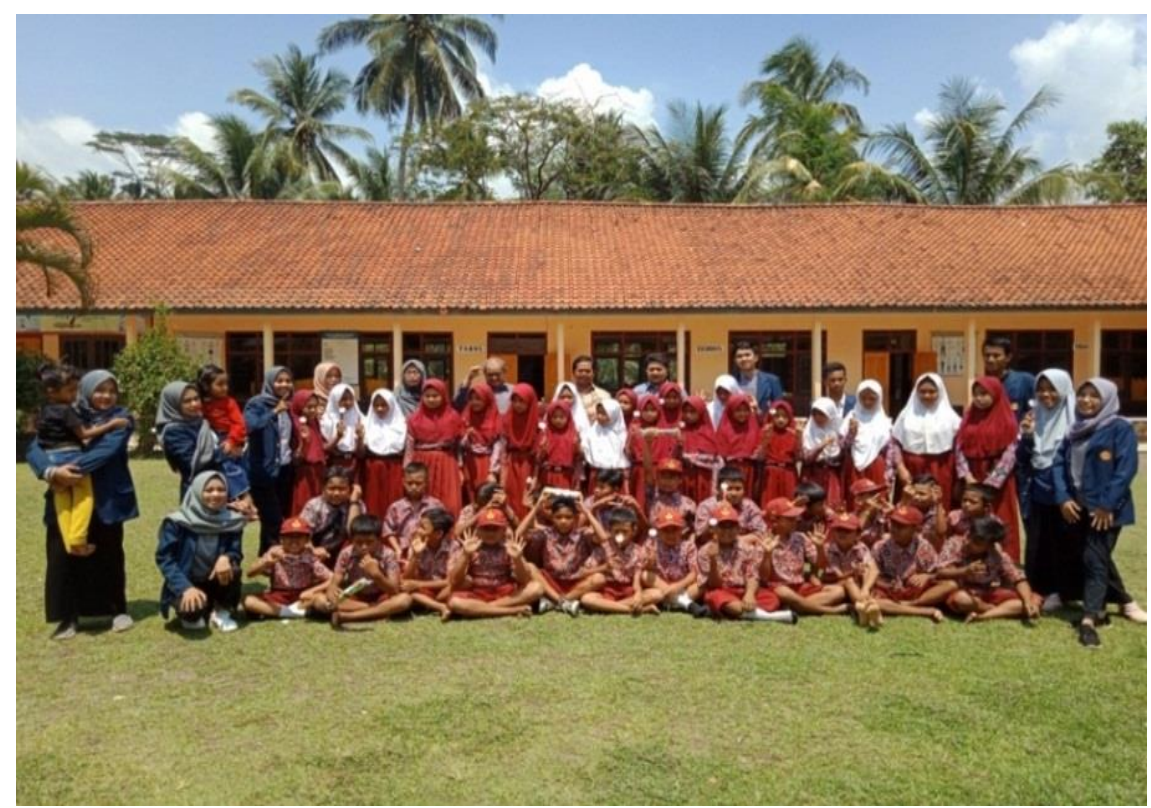

Gambar 4: Photo Bersama Setelah Kegiatan Pengabdian Selesai

Dampak dari pengabdian ini terdiri dari dampak jangka pendek dan jangka panjang. Dampak jangka pendeknya adalah terjadinya peningkatan keterampilan tentang cara-cara mencuci tangan yang benar ditinjau dari segi kesehatan. Sedangkan dampak jangka panjangnya adalah dapat memutus rantai penularan setiap penyakit infeksi seperti disentri, kolera, TBC, bronkhitis, malaria, DBD, dan cacingan (Najmah, 2015). Dengan meningkatnya pengetahuan siswa tentang manfaat cuci tangan pakai sabun, maka siswa akan memiliki kebiasaan berperilaku pola hidup besrsih dan sehat. Dengan kebiasaan baru siswa tentang cuci tangan, maka siswa akan terhindar dari bebagai penyakit infeksi tersebut.

\section{SIMPULAN}

Setelah dilakukan penyuluhan melalui metoda demonstrasi, maka kegiatan pengabdian ini dapat disimpulkan bahwa terdapat peningkatan keterampilan tentang cara mencuci tangan yang benar pada siswa SDN 03 Cintakarya Pangandaran. Keterampilan ini kemudian diterapkan dalam kehidupan sehari-hari untuk menghambat penularan penyakit infeksi menular.

\section{UCAPAN TERIMA KASIH}

Pada kesempatan ini penulis mengucapkan terimakasih pada rektor Universitas Padjadjaran, dekan Fakultas Keperawatan, kepala sekolah SDN 03 Cintakarya, guru-guru dan para staf lainnya, juga para mahasiswa Fakultas Keperawatan Universitas Padjadjaran 
PSDKU Pangandaran, karena atas segala bantuannya, maka artikel PPM ini dapat tersusun dengan lancar, semoga segala kebaikannya dibalas oleh Allah s.w.t. aamiin.

\section{DAFTAR PUSTAKA}

Desiyanto, F.A., \& Djannah, S. N. (2013). Efektivitas Mencuci Tangan Menggunakan Cairan Pembersih Tangan Antiseptik (Hand Sanitizer) Terhadap Jumlah Angka Kuman. Jurnal Kesehatan Masyarakat (Journal of Public Health), 7(2), 75-82. https://doi.org/10.12928/kesmas.v7i2.1041

Dinkes Propinsi Jawa Barat.(2015). Profil Kesehatan Propinsi Jawa Barat Tahun 2015. Dinkes Prop. Jawa Barat.

Evayanti. (2014). Faktor-Faktor Yang Berhubungan Dengan Kejadian Diare Pada Balita Yang Berobat Ke Badan Rumah Sakit Umum Tabanan. Jurnal Kesehatan Lingkungan. Vol 4. No. 2. November 2014

Kementerian Kesehatan RI. (2014). Perilaku Cuci Tangan Pakai Sabun. In Pusdatin Kemenkes RI (p. 3).

Maryunani, A. (2013). Perilaku Hidup Bersih Dan Sehat. Jakarta: Trans Info Media.

Murwani, S. (2015). Dasar-dasar Mikrobiologi Veteriner. Edisi 1 Malang: Universitas Brawijaya Press.

Murwanto, B. (2017). Faktor Perilaku Cuci Tangan Pakai Sabun (CTPS) di SMP. Jurnal Kesehatan, 8(2), 269. https://doi.org/10.26630/jk.v8i2.445

Najmah.(2016). Epidemiologi Penyakit Menular. Jakarta: Trans Info Media.

Rosyidah, A. N. (2014). Hubungan Perilaku Cuci Tangan Terhadap Kejadian Diare Pada Siswa di SDN Ciputat 02. Skripsi. Jakarta: Universitas Islam Negeri Syarif Hidayatullah. $\quad$ http://repository.uinjkt.ac.id/dspace/bitstream/ 123456789/2.Alif\%20Nurul\%20Rosyidah\%20-\%20fkik\%20

Widoyono. (2012). Penyakit Tropis: Epidemiologi, Penularan, Pencegahan dan Pemberantasannya. Jakarta: Penerbit Erlangga.

World Health Organization.(2013). Soil-Transmitted Helminthiases: Eliminating Soil-Transmitted Helminthiases as a Public Health Problem in Children: WHO Department of Control of Neglected Tropical Diseases. 